\title{
Assessment of groundwater to pollution by the toxic metals in the municipality of Kerou (Benin) in watershed of the Niger
}

\author{
Bernadin ELEGBEDE ${ }^{1}$, A. Patrick EDORH ${ }^{2,4 *}$, Luc KOUMOLOU ${ }^{3}$, S. Armelle \\ HOUNKPATIN $^{4}$, Patient GUEDENON ${ }^{4}$, A. Yvette DEGUENON ${ }^{4}$ and Michel BOKO \\ ${ }^{1}$ Direction Départementale de l'Hydraulique, Ouémé-Plateau, 04 BP 1412, Bénin. \\ ${ }^{2}$ Département de Biochimie et de Biologie Cellulaire, Université d'Abomey-Calavi (UAC), \\ 01 BP 526 Cotonou, Bénin. \\ ${ }^{3}$ Département de Physiologie/Pharmacologie, Faculté des Sciences, Université de Lomé (UL), \\ BP 1515 Lomé, Togo. \\ ${ }^{4}$ Centre Interfacultaire de Formation et de Recherche en Environnement pour le Développement Durable \\ (CIFRED), Université d'Abomey-Calavi (UAC), 03 BP 1463, Jéricho, Cotonou, Bénin. \\ ${ }^{5}$ Laboratoire Pierre Pagney : Climat, Eau, Ecosystème et Développement (LACEEDE), \\ 03 BP 1122 Cotonou, Bénin. \\ *Corresponding author; E-mail: patrickedorh@yahoo.fr ; Tél : 00 (229) 9707 15 96,
}

\begin{abstract}
This case study has assessed the vulnerability of boreholes water to pollution by toxic metals in the cotton zone of Kerou, in northern Benin. Toxic metals (lead, copper, cadmium, zinc, nickel and iron) were analyzed by atomic absorption spectrophotometry. The results show high values for lead, nickel and iron, which means that 7 out of 18 boreholes are contaminated. Only the lead level exceeds the standard for the boreholes of Ganbore and Korigourou $(0.0613$ and $0.098 \mathrm{mg} / \mathrm{l}$ against $0.04 \mathrm{mg} / \mathrm{l})$ The level of contamination of Cadmium, zinc and copper is very irregular, but however one must notice that the two aforementioned boreholes are contaminate with the concentration of cadmium above the permitted limit $(0.0234$ and 0.0244 $\mathrm{mg} / \mathrm{l}$ against $0.005 \mathrm{mg} / \mathrm{l}$ ). These findings allow us to say that, apart from the two boreholes of the localities of Ganbore and Korigourou located in cotton farm, most of the boreholes are resistant to pollution. So the responsible factors, of the noticed contamination are defined. It is above all due to the cultivation of cotton in this area. The assays witness of the Mekrou River has revealed high contamination by lead $(0.060 \mathrm{mg} / \mathrm{l})$ and the iron $(1.4341 \mathrm{mg} / \mathrm{l})$ : this result can highlight the ongoing relationship of surface water with groundwater.

(C) 2011 International Formulae Group. All rights reserved.
\end{abstract}

Keywords: Vulnerability, groundwater, contamination, toxic metals, cotton culture.

\section{INTRODUCTION}

Human health depends on the availability in sufficient quantity and in the quality of water. Groundwater, main source of drinking water is powered by rainwater that enters by gravity into the pores and cracks in rocks (Benaabidate, 2000).
Groundwater is reached through the achievement of wells and boreholes. According to the structure in charge of drinking water, there are about 2153 large diameter wells and 4291 boreholes with hand pumps in Benin, the City of Kérou 
has only 30 wells and approximately 102 boreholes (Elégbédé, 2007). This case study has been chosen for many reasons. Due to their large number, boreholes are used for drinking water unlike wells. Moreover, recent studies have revealed the chemical and bacterial pollution of well water compared to boreholes that appear to be more protected (Elégbédé, 2007). The technical configuration of the well was identified as the main course for the vulnerability: often shallow, open, sometimes directly subject to human pressures (Ouadaogo-Yaméogo, 2008). These researches, which are now very frequent, alert people who are becoming more and more reluctant to this water. However, boreholes have some technical credibility that would ensure the safety of water for consumption. However, the potability of water, which mainly considers as physico-chemical and bacteriological parameters, can no longer hide the pollution by heavy metals. The magnitude of the population that takes these products in the beninese environment no longer allows this lack of interest. Indeed, in Benin, more researches have revealed high contents of toxic metals in staple foods: giants snails of Okpara (Edorh et al., 2009), sediments and water of Lake Nokoué (Edorh et al., 2010). Furthermore, Adam et al. (2010) have found lead in water pump in Banikoara. However, some toxic metals, beyond the usual chemical elements of potability, are particularly dangerous for the immune system, skin, circulatory system (Testud, 2005), the central nervous system, liver and kidneys (Viala and Grimaldi, 2005). Despite the clinical signs recorded in our hospitals resemble some metals diseases; doctors have paid little attention to this issue (Edorh, 2007). This study has therefore proposed to assess the vulnerability of boreholes with hand pumps type UPM or VERGNET, particularly to the pollution by toxic metals in the cotton zone of Kerou. The goal is to see if the effect of promoting the drilling at the expense of wells would not be sufficient as a preventive measure against the risks associated with poor water quality. Therefore, we should also consider the impact of human activities on the vulnerability of water resources.

\section{MATERIALS AND METHODS \\ Study area}

Kerou municipality is limited to the North-West by the Municipality of Tanguieta with which it shares the Pendjari Park and to the North-East by the Municipality of Banikoara which is the largest producer of cotton at the national level. In the South, it shares its borders with the cotton belt of Pehonco, and Kouande Gogounou. It is divided into four Districts that are Brignamaro, Kerou, Centre Kaobagou and Firou.

The climate of the region is governed by the North Sudanese regime characterized by two distinct seasons: a dry October to April and rainy from May to September.

The study area is located in the watershed of the Niger which is controlled by the streams tributary of Pendjari such as the Sota and Mekrou.

Rainfall gives around 900 to $1000 \mathrm{~mm}$ of water per year. Its hydrogeology is dominated by Precambrian granitic-gneiss covered with a thick layer of clay-altered lateritic. Infiltration of rainwater is very intense due to the high density of the fracture network and the nature of the soil generally clay-lateritic with high permeability. The crystalline basement consists of igneous and metamorphic waterproof rocks, facilitating run-off chemical substances in the beds of rivers. These geological formations explain the nature and properties of soils which are extremely fragile. The area is dominated by cotton cultivation with uncontrolled use of pesticides and fertilizers. They are sometimes undeniable sources of metals found in the river before penetrating in the groundwater. 


\section{Sampling and analysis}

Water points were chosen so as to have an overall picture of water surrounding the Mékrou River, with the aim to detect the possible interaction between the groundwater and the Mékrou River. In this study eighteen (18) samples come from groundwater (boreholes) and one from Mékrou River in nineteen (19) which were taken.

The samples were taken during the month of December in the dry season to evaluate the increase of the concentration of chemical elements due to the low water.

Mékrou River (F19) was taken to test the hypothesis of the interaction between groundwater and river, in fact drillings with high contents of lead are those which are closed to Mékrou River or situated in the field of cotton.

\section{Treatment and analysis}

Measurements of temperature, $\mathrm{pH}$, total hardness and electrical conductivity were performed in situ.
The $\mathrm{pH}$ of the water analyzed is measured using the $\mathrm{pH}$-indicator strips. The conductivity was measured by a conductivity meter. Most measurements of these parameters are normal for boreholes

Toxic metals (lead, cadmium, zinc, copper, nickel and iron) are analyzed in the laboratory by atomic absorption spectrophotometry according to the protocols (Anane et al., 1995; Vaidya et al., 1996). The data were represented by spots blots in Excel.

\section{RESULTS}

Seven out of eighteen samples contain lead at varied levels, but this depending on whether boreholes are near the cotton field or they are closed to the Mékrou River.

Figure 2 shows the concentrations of various toxic metals analyzed in the boreholes water of Kerou town.

Figure 1 shows the location of water points in these four districts

Table 1: Distribution of boreholes (F) in the districts of Kerou.

\begin{tabular}{|c|c|c|c|}
\hline Boreholes & Districts & Populations (PDC, 2006) & Localities \\
\hline F1 & \multirow{4}{*}{ Firou } & \multirow{4}{*}{10.204} & Firou market \\
\hline $\mathrm{F} 2$ & & & Camp peul -EPP \\
\hline F3 & & & Ferme Gérant \\
\hline F4 & & & Marékpo \\
\hline F5 & & & Ganboré \\
\hline F6 & \multirow{5}{*}{ Kerou } & \multirow{5}{*}{27.889} & Gantodo EPP \\
\hline F7 & & & Toundagou \\
\hline F8 & & & Center \\
\hline F9 & & & Boni \\
\hline F10 & & & Konigourou Center \\
\hline F11 & \multirow{9}{*}{ Brignamaro } & \multirow{9}{*}{12.687} & Kossou-Nord \\
\hline F12 & & & Kossou-Sud \\
\hline F13 & & & $\mathrm{CCS}$ \\
\hline F14 & & & Ouinra-Center \\
\hline F15 & & & Bérékossou \\
\hline F16 & & & Banbaba \\
\hline F17 & & & Wodora \\
\hline F18 & & & Boukaro \\
\hline F19 & & & Mékrou River \\
\hline
\end{tabular}




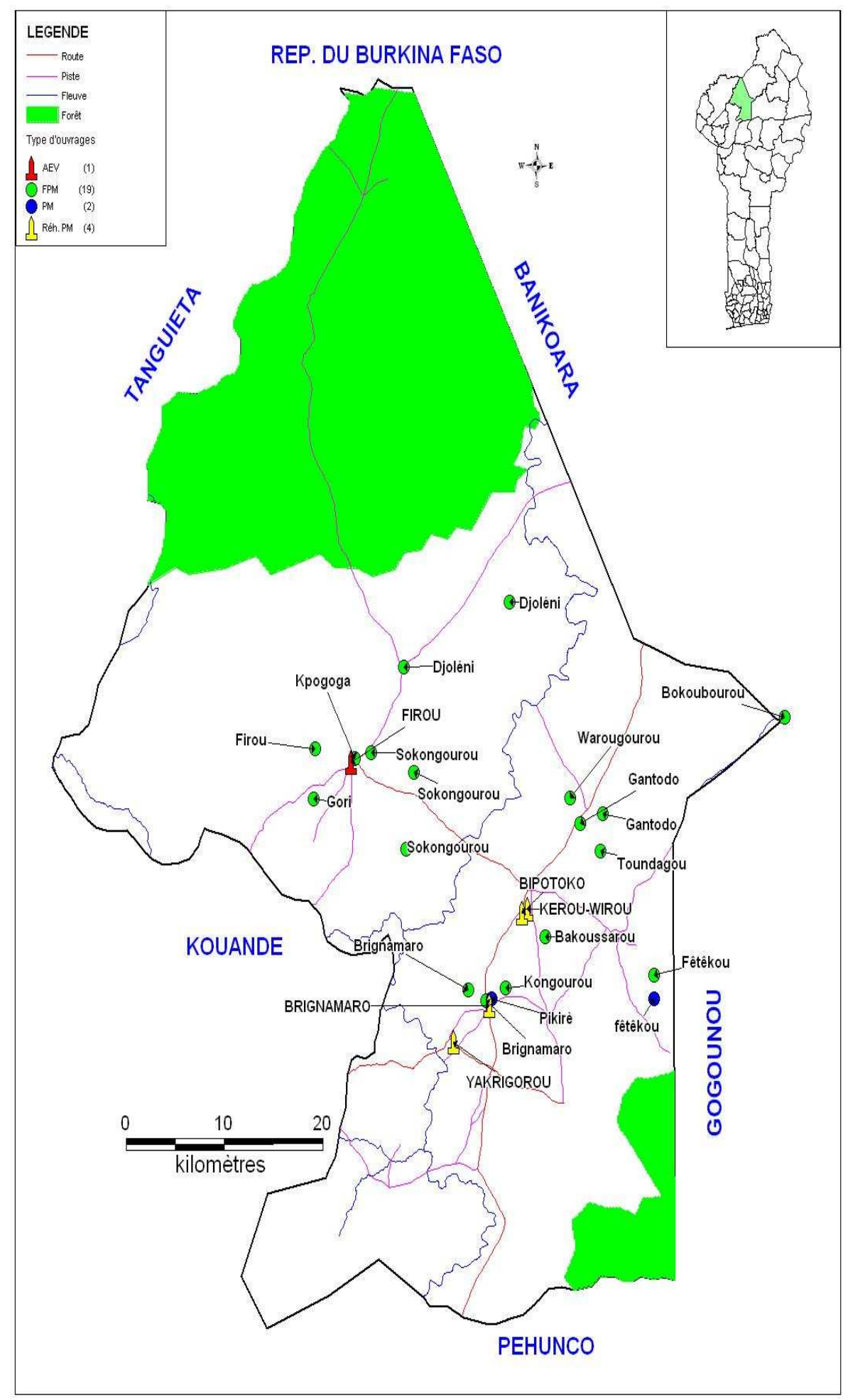

Figure 1: shows the location of water points in these four districts. 


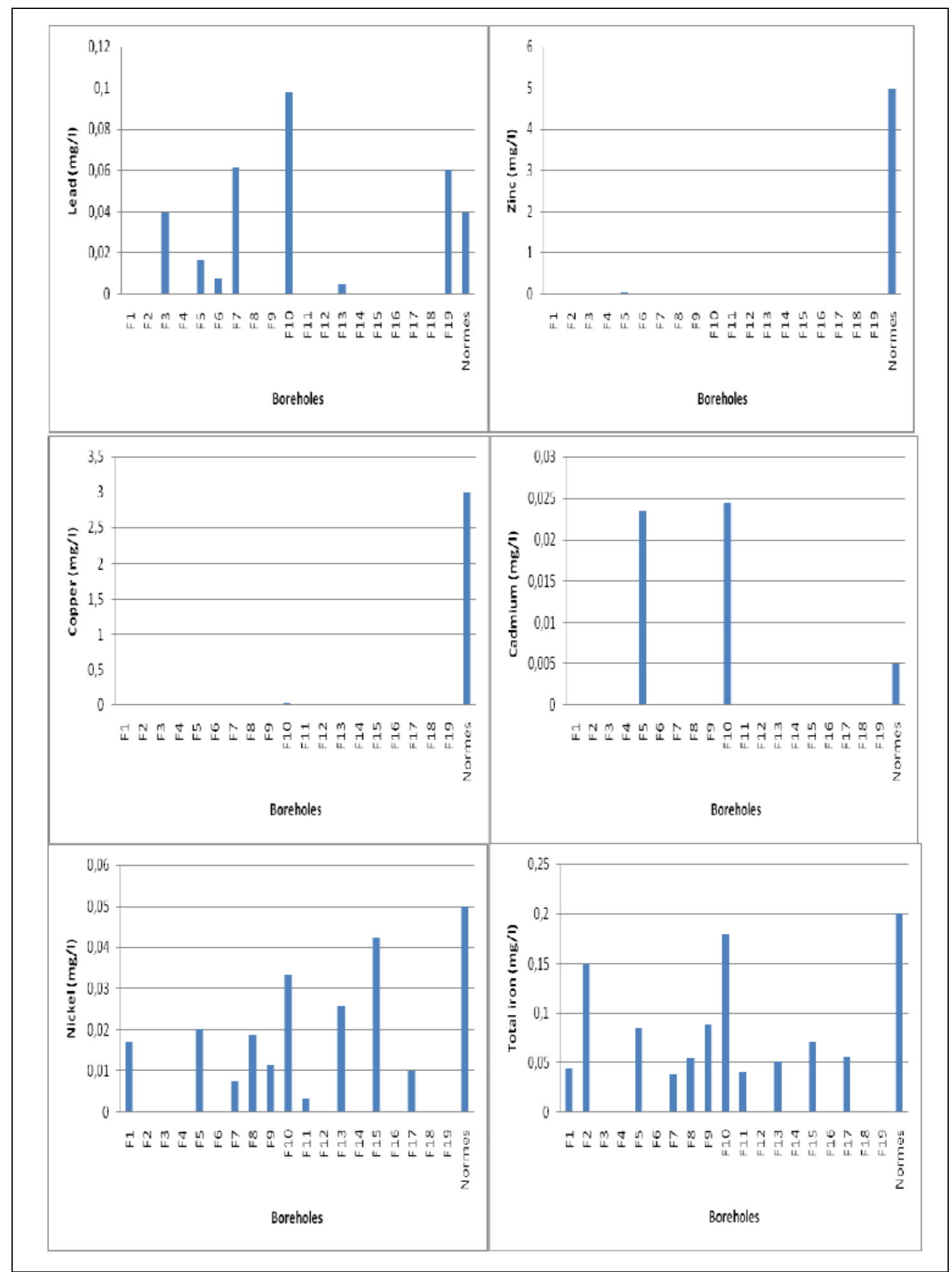

Figure 2: Concentrations of various toxic metals in the boreholes water at Kerou. F20 is the WHO standard for safe drinking water (WHO, 2001). 


\section{DISCUSSION}

\section{Copper and lead}

Copper and lead are subjects to regulation jointly because both are normally used in plumbing. Because they are corrosive it is normal to find copper in quantities of a few tenths of ppm and this does not pose a risk. Figure 2 shows that, apart from drilling F5 and F10, Kerou waters do not contain copper or rather the detection limits of the spectrophotometry does not allow to identify the presence of copper. Drilling F5 and F10, Ganbore and Konigourou recorded respectively 0.0122 and $0.0270 \mathrm{mg} / \mathrm{l}$ of copper in their water against the limit of $3 \mathrm{mg} / \mathrm{l}$. Regarding lead, the most significant heavy metal, for both toxic and widespread (Boutron and Patterson, 1983), enter the water during the corrosion of plumbing materials. It can be found in the solders used to join copper pipes, as well as fittings and brass valves. The assay results show that of the 18 samples of boreholes water, 2 drillings; F7 and F10, respectively Toundagou and Korigourou contain 0.0613 and $0.098 \mathrm{mg} / \mathrm{l}$ of $\mathrm{Pb}$ against the permissible limit of $0.04 \mathrm{mg} / \mathrm{l}$. These boreholes in the borough of Kerou are characterized by strong agriculture pressure. In addition, the poor management of household waste can also be questioned (Feuillade et al., 2001). These data must be taken very seriously especially with regard to children for whom lead poisoning is more dangerous (Peden et al., 2009). Even at low doses may cause intoxication. It can be observed in children poisoned, a change in the maturation of the nervous system with delayed motor development (Galaf and Ghannam, 2003), impaired memory and hearing problems (François-Henri et al., 2004). Lead can cause blood disorders, gastrointestinal, reproductive, and immunological and apoptotic disorders (Patrick, 2006; Xu et al., 2008)

\section{Cadmium and zinc}

Cadmium occurs mostly in association with zinc and enters the water during the corrosion of galvanized pipes and fittings, coated with zinc. The results presented in Figure 2 show trace amounts of zinc $(0.0354$ and $0.0260 \mathrm{mg} / \mathrm{l}$ respectively for drilling F5 and $\mathrm{F} 10$ against a limit of $5 \mathrm{mg} / \mathrm{l}$ ). This does not pose a risk. Indeed, zinc, trace element essential for replication and translation of genetic material (Galder and Vallee, 1983) becomes toxic at high doses. And again, no toxicity was reported for zinc food borne (Prasad et al., 1979). However, teratogenic effects (Campbell and Mills, 1979) and disorders of cholesterol metabolism (Klevay, 1980) occur when there is competition with copper. With regard to cadmium, these results show that it is 5 times more concentrated than normal water in these wells F5 and F10 $(0.0234$ and $0.0244 \mathrm{mg} / \mathrm{l}$ to a limit of 0.005 $\mathrm{mg} / \mathrm{l})$. It is always in big concentration at Ganboré and Konigourou villages. The garbage accumulated in dumps breaching the standard (landfill site) produce leachates rich in lead and cadmium (Feuillade et al., 2001). But cadmium, unlike lead adsorbs weakly soil particles (Camobreco et al., 1996). It is freer and lets itself be dragged into the depths and contaminate groundwater (Richards et al., 1998). Excessive exposure to cadmium may cause death (Othumpangat et al., 2005). It enters cells and accumulates in high concentrations in cytoplasm and nuclear space (Beyersmann et al., 1997) and has a strong affinity for the liver and kidneys (Cai et al., 2001).

\section{Nickel and iron}

The results in Figure 2 show that iron and nickel are to be monitored, particularly at the borehole F10 (0.0334 and $0.1789 \mathrm{mg} / \mathrm{l})$; concentration of nickel $(0.0425 \mathrm{mg} / \mathrm{l})$ in drilling F15 and concentration of iron (0.1493 $\mathrm{mg} / \mathrm{l}$ ) in drilling F2 are too high even if they don't reach the standard, they are too closed to the respective limits of $0.05 \mathrm{mg} / \mathrm{l}$ and 0.2 $\mathrm{mg} / \mathrm{l}$. The Iron is quite abundant in the rocks where it is in the form of silicates, oxides, hydroxides, carbonates and sulfides. In groundwater, iron is often under reducing conditions. 
But this iron precipitates in an oxidizing environment (Gone et al., 2008), particularly at source and when leaving water pipes. Moreover, the quantities necessary to meet the lethal dose is $0.04 \mathrm{mg} / \mathrm{l}$ and can cause carcinogen, nausea, vomiting, diarrhea, allergic contact dermatitis, pulmonary asthma, conjunctivitis, inflammatory reaction.

The presence of these metals pose a risk, they also cause many inconveniences in appearance and taste of water. It is not the case with the lead and cadmium that make the water unusable for drinking, domestic use and agriculture. For this, involvement and awareness of local environmental rules after the completion of drilling should help prevent the manifestation of pollution to ensure efficient and sustainable management of water resources. Finally, the results of control assays of the Mekrou River show contamination for lead.

\section{Conclusion}

The results of the vulnerability assessment of the well from pollution by toxic metals indicate that lead, nickel and iron have contaminated nearly half of the wells studied, but only lead levels exceed the standards and that in two boreholes. By consequence, contamination by cadmium, zinc and copper is very irregular; only Ganbore and Korigourou boreholes are contaminated with cadmium levels above the legal limit. In short, lead and cadmium pose real risks to the health of people in two boreholes situated at Ganbore and Korigourou communities. It can be assured that the cause of this contamination is localized and can be attributed to the intensive cultivation of cotton in the region, where the boreholes are located. But it can also depend on poor hygiene and sanitation around these boreholes. Finally, the results obtained through the various tests are worrying to increase the monitoring of water in the watershed of River Niger with series of awareness in order to preserve the life and ecosystems in the area.

\section{REFERENCES}

Anane R, Bonini M, Grafeille MJ, Creppy EE. 1995. Bioaccumulation of water soluble aluminum chloride in the hippocampus after transdermal uptake in mice. Arch. Toxicol., 69: 568-571.

Benaabidate L. 2000. Caractérisation hydrologique du bassin versant de Sebou: hydrogéologie qualité des eaux et géochimie des eaux thermales. Thèse de doctorat. Es-sc. F.S.T. Fès, p. 250.

Beyersmann D, Hechtenberg S. 1997. Cadmium gene regulation and cellular signaling in mammalian cells. Toxicol. Appl. Pharmacol., 144: 247-261.

Boukari M. 2001. Identification des aquifères de la zone littorale du Bénin Afrique de l'ouest : Hydrodynamique Hydrochimie et problèmes d'alimentation en eau de la ville de Cotonou. Africa Geosciences Review, 2(1): 121-139.

Boutron CF, Patterson CC. 1983. The occurrence of lead in Antarctic recent snow firns depostited over the last two centuries and prehistoric ice. Geochim. Cosmochim. Acta., 47: 1355- 1368.

Cai Y, Aoshima K, Katoh T, Teranishi H, Kasuya M. 2001. Renal tubular dysfunction in male inhabitants of a cadmium-polluted area in Toyama Japanan eleven-year follow-up study. $J$. Epidemiol., 11: 180-189.

Camobreco VJ, Richards BK, Steenhuis TS, Peverly JH, McBride MB. 1996. Movement of heavy metals through undisturbed and homogenized soil columns. Soil Science, 161: 740-750.

Campbell JK, Mills CF. 1979. Toxicity of zinc to pregnant sheep. Environ. Res., 20(1): 1-13.

Edorh AP, Agonkpahoun E, Gnandi K, Guédénon P, Koumolou L, Amoussou C, Ayedoun A, Boko M, Gbeassor M, Rihn H, Creppy E. 2009. An assessment of the contamination of Achatina achatina by toxic metals in Okpara village. Int. J. Biol. Chem. Sci., 3(6): 1428 -1436. 
Edorh AP, Gnandi K, Ayedoun MA, Agonkpahoun E, Koumolou L, Amoussou C, Boko M, Gbeassor M, Rihn HB, Creppy EE. 2010. Etude comparative de la bioaccumulation de métaux lourds dans les sédiments du lac Nokoué et de la rivière Okpara (Bénin). Sciences et Médecine Rev. CAMES - A (10).

Edorh A. 2007. Heavy metals actions. TWAS Newsletter, 9(2) : P. 52-45.

Elégbédé MB. 2007. Pollution de l'eau des puits et de la nappe phréatique par les pratiques humaines et son impact sur la sante des populations dans la commune de kerou, premier producteur du coton dans les départements de l'atacora/donga. DEA, p.111.

Feuillade G. Lagier T. Matejka G. 2001. Les métaux lourds dans les décharges d'ordures ménagères. La Tribune de l'Eau, 54 (611) : 17-24.

François-Henri B, Jean CQ, François B. 2004. Sécurité sanitaire des aliments : Parlonsen ! 13p.

Galaf F, Ghannam S. 2003. Pollution $d u$ Milieu Marin. Institut Agronomique Vétérinaire : Hassan II Rabat (Ma) ; 115.

Othumpangat S, Kashon M, Joseph P. 2005. Eukaryotic translation initiation factor $4 \mathrm{E}$ is a cellular target for toxicity and death due to exposure to cadmium chloride. $J$. Biol. Chem., 280: 162-169.

Ouadaogo-Yaméogo S. 2008. Ressources en eau souterraine du centre urbain d'Ouagadougou au Burkina Faso : qualité et vulnérabilité. Thèse Académie d'AixMarseille Univ. D'Avignon et des Pays de Vaucluse, Paris, pp 88-1125.

Patrick L. 2006. Lead toxicity part II: the role of free radical damage and the use of antioxidants in the pathology and treatment of lead toxicity. Altern. Med. Rev., 11: 114-127.

PDC Programme d'appui au démarrage des communes Monographie de la commune de Kerou 2006. Mission de
Décentralisation document de travail. Bénin; p. 30-35.

Peden M, Oyebite K, Ozanne-Smith J, Hyder AA, Branche C, Rahman FA, Rivara F. 2009. Rapport mondial sur la prévention des traumatismes de l'enfant. World Health Organization ; p. 250.

Prasad AS, Brewer GJ, Schoomaker EB, Rabbani P. 1979. Hypocupremia induced by zinc therapy in adults. J. Am. Med. Assoc., 240: 2166.

Richards BK, Steenhuis TS, Peverly JH, Mc Bride MB. 1998. Metal mobility at an old heavily loaded sludge application site. Environ. Pollut., 99: 365- 377.

Soulé Adam, Edorh PA, Totin H, Koumolou L, Amoussou E, Aklikokou K, Boko M. 2010. Pesticides et métaux lourds dans l'eau de boisson les sols et les sédiments de la ceinture cotonnière de Gogounou Kandi et Banikoara (Bénin). Int. J. Biol. Chem. Sci., 4(4): 105-114.

Testud F. 2005. Pathologie toxique professionnelle et environnementale 3ème éd Eska, Paris, p. 672.

Vaidya CO, Rantala TTR. 1996. A comparative study of analytical methods determination of heavy metal in mussels (Mytilis edulis) from eastern Canada. Int. Environ. Anal. Chemistry., 63(3): 179185.

Viala A, Grimaldi F. 2005. Ecotoxicologie. In Eléments de Toxicologie (2è édn), Viala A, Botta A. Tec \& Doc Lavoisier : Paris ; 245-251.

Xu J, Lian L, Wu C, Wang XF, Fu WY, Xu LH. 2008. Lead induces oxidative stress DNA damage and alteration of p53 Bax and Bcl-2 expressions in mice. Food Chem. Toxicol., 46: 1488-1494. 